\title{
Respons Morfologis Beberapa Varietas Padi (Oryza sativa L.) terhadap Kekeringan pada Fase Perkecambahan (Morphological Response of Some Rice (Oryza sativa L.) Cultivars to Water Deficit at the Seedling Stage)
}

\author{
Maria Ballo ${ }^{1)^{*}}$, Nio Song A ${ }^{2)}$, Dingse Pandiangan ${ }^{2)}$, Feky R Mantiri ${ }^{2)}$ \\ ${ }^{1)}$ Alumni Jurusan Biologi Fakultas MIPA Universitas Sam Ratulangi Manado \\ 2) Jurusan Biologi Fakultas MIPA Universitas Sam Ratulangi Manado \\ *E-mail korespondensi: radhitya27dede@yahoo.co.id
}

Diterima 1 Juli 2012, diterima untuk dipublikasikan 1 Agustus 2012

\begin{abstract}
Abstrak
Biji memerlukan sejumlah besar air yang harus diserap sebelum perkecambahan bisa terjadi, yaitu sekitar dua atau tiga kali dari berat keringnya. Penelitian ini menguji konsistensi respons morfologis padi terhadap kekeringan pada fase perkecambahan dengan perlakuan larutan polietilen glikol (PEG) sebagai larutan osmotikum. Penelitian ini dilakukan dengan percobaan faktorial dalam Rancangan Acak Kelompok yang terdiri dari 5 perlakuan PEG 8000 mencakup PEG 0, -0,25, 0,5, -0,75 dan -1,0 MPa terhadap 7 varietas padi, yaitu Beras Merah, IR 64, Burungan, Superwin, Serayu, Aries, dan Cigeulis. Hasil penelitian ini menunjukkan terdapat perbedaan respons morfologis terhadap kekeringan yang diinduksi dengan PEG 8000 pada fase perkecambahan di antara ketujuh varietas padi. Panjang akar seminal, panjang tunas, rasio panjang akar seminal : panjang tunas, persentase perkecambahan dan indeks vigor benih dapat dipakai sebagai indikator toleransi kekeringan yang potensial pada fase perkecambahan padi. Toleransi varietas Superwin terhadap kekeringan yang diinduksi dengan PEG 8000 pada fase perkecambahan lebih tinggi daripada varietas padi lainnya.

Kata kunci: indikator, PEG, toleransi, kekeringan
\end{abstract}

\section{Abstract}

The seeds required a large amount of water, i.e. two or three times of their dry weight, to be absorbed before the germination. This study evaluated the consistency of morphological response of rice to water deficit at the seedling stage. The research was conducted as factorial experiment in Randomized Block Design. The treatments of PEG-8000-induced-water deficit were PEG 0,-0,25, -0,5, -0,75 and -1,0 MPa. Those treatments were applied to 7 rice cultivars, i.e. Beras Merah, IR 64, Burungan, Superwin, Serayu, Aries, and Cigeulis. The results showed the difference of morphological response to PEG-8000-induced-water deficit among 7 rice cultivars at the seedling stage. The seminal root length, shoot length, ratio seminal root length: shoot length, seedling percentage and seed vigor index were able to be used as potential water-deficit-tolerant indicators at the seedling stage. Cultivar Superwin was more tolerant to PEG 8000-induced- water deficit than 6 other rice cultivars.

Keywords: PEG, indicator, water- deficit tolerant

\section{PENDAHULUAN}

Pada perkecambahan, air sangat berperan penting untuk terjadinya perkecambahan, karena sebagian besar biji mempunyai kandungan air yang relatif rendah dan perkecambahan dimulai dengan 
penyerapan air (Mayer dan Mayber 1963 dalam Nio dan Ballo 2010). Biji memerlukan sejumlah besar air yang harus diserap sebelum perkecambahan bisa terjadi (Gardner et al. 1991), yaitu sekitar dua atau tiga kali dari berat keringnya (Stefferud 1961 dalam Nio dan Ballo 2010).

Beberapa metode dapat digunakan untuk menguji toleransi kekeringan dalam program pemuliaan tanaman (Winter et al. 1988), antara lain pengukuran kerapatan dan kedalaman akar (Gregory 1989), perbandingan biomassa akar dan pucuk, kandungan air dalam daun (Kumar dan Singh 1998), stabilitas osmotik membran (Premchandra et al. 1990), perkecambahan dalam larutan osmotikum (Emmerich dan Haregree 1991). Penelitian ini merupakan penelitian lanjutan untuk menguji konsistensi respons morfologis terhadap kekeringan pada fase perkecambahan dengan macam varietas padi dan larutan PEG yang lebih banyak. Dalam penelitian ini digunakan 7 macam varietas padi dan 5 macam larutan PEG sebagai larutan osmotikum.

\section{METODE PENELITIAN}

Penelitian ini dilakukan selama bulan Mei 2011 di Laboratorium Biologi Konservasi dan Diversitas Jurusan Biologi FMIPA UNSRAT. Alat yang digunakan gelas ukur, gelas kimia, pipet tetes, timbangan analitik, hot plate, pengaduk, pinset, container (panjang $20 \mathrm{~cm}$, lebar $15 \mathrm{~cm}$, dan tinggi $5 \mathrm{~cm}$ ) yang berfungsi sebagai tempat perkecambahan benih dan pipet yang berfungsi sebagai penyedot larutan. Bahan yang digunakan dalam penelitian ini antara lain pemutih komersial, kertas filter, tissue, akuades, PEG 8000 dan benih dari 7 varietas padi.
Penelitian ini dilakukan dengan percobaan faktorial dalam Rancangan Acak Kelompok yang terdiri dari 5 perlakuan polietilen glikol (PEG) 8000 pada 7 varietas padi dalam 3 kali ulangan. Perlakuan PEG 8000 mencakup PEG $0,-0,25,-0,5,-0,75$ dan -1,0 $\mathrm{MPa}$. Varietas padi yang akan digunakan adalah Beras Merah, IR 64, Burungan, Superwin, Serayu, Aries, Cigeulis.

Biji dikatakan berkecambah jika panjang radicula mencapai $2 \mathrm{~mm}$. Persentase perkecambahan diamati setiap hari, sedangkan panjang akar seminal, panjang tunas, diukur pada akhir percobaan dan rasio panjang akar seminal : panjang tunas dan indeks vigor benih juga dihitung pada akhir penelitian. Persentase perkecambahan (\%) dihitung dengan rumus (jumlah benih yang berkecambah/total benih yang dikecambahkan) X $100 \%$, sedangkan indeks vigor benih dihitung dengan rumus (panjang akar seminal + panjang pucuk) $X$ persentase perkecambahan (modifikasi dari Dhanda et al. 2004, Dezfuli et al. 2008). Semua data yang diperoleh dianalisis dengan Analisis Varian. Jika terdapat perbedaan yang nyata, analisis dilanjutkan dengan uji BNT $5 \%$.

\section{HASIL DAN PEMBAHASAN Panjang Akar Seminal}

Panjang akar seminal dari 7 varietas padi dengan 5 macam perlakuan PEG dapat dilihat pada Tabel 1. Hasil analisis sidik ragam menunjukkan bahwa faktor varietas, PEG, dan interaksi antara faktor varietas dan PEG menyebabkan perbedaan panjang akar yang nyata sehingga dilanjutkan dengan uji BNT $5 \%$.

Panjang akar pada Beras Merah pada perlakuan PEG $0 \mathrm{MPa}$ lebih 
besar dibandingkan dengan perlakuan PEG $-0,25,-0,5$ bahkan tidak terlihat adanya akar seminal yang tumbuh pada perlakuan PEG $-0,75$ dan -1 . Panjang akar pada IR 64 pada perlakuan PEG 0 lebih besar dari

Tabel 1. Panjang akar seminal $(\mathrm{cm}) 7$ varietas kecambah padi dengan 5 macam perlakuan PEG (Rata-rata \pm Standar Deviasi)

\begin{tabular}{llllll}
\hline \multirow{2}{*}{ Varietas } & \multicolumn{5}{c}{ PEG (MPa) } \\
\cline { 2 - 6 } & \multicolumn{1}{c}{0} & \multicolumn{5}{c}{$-0,25$} & $-0,5$ & $-0,75$ & -1 \\
\hline Beras Merah & $4,2 \pm 0,2 \mathrm{i}$ & $3,1 \pm 1,01 \mathrm{gh}$ & $2,7 \pm 1,02 \mathrm{efg}$ & $0,0 \pm 0,0 \mathrm{a}$ & $0,0 \pm 0,0 \mathrm{a}$ \\
IR 64 & $4,2 \pm 0,17 \mathrm{i}$ & $2,9 \pm 0,41 \mathrm{fgh}$ & $0,0 \pm 0,0 \mathrm{a}$ & $0,0 \pm 0,0 \mathrm{a}$ & $0,0 \pm 0,0 \mathrm{a}$ \\
Burungan & $3,5 \pm 0,5 \mathrm{hi}$ & $2,7 \pm 0,6 \mathrm{efg}$ & $0,0 \pm 0,0 \mathrm{a}$ & $0,0 \pm 0,0 \mathrm{a}$ & $0,0 \pm 0,0 \mathrm{a}$ \\
Superwin & $2,4 \pm 0,14 \mathrm{efg}$ & $2,4 \pm 0,1 \mathrm{efg}$ & $1,9 \pm 0,17 \mathrm{de}$ & $0,9 \pm 0,53 \mathrm{~b}$ & $2,2 \pm 0,47 \mathrm{def}$ \\
Serayu & $2,5 \pm 0,07 \mathrm{efg}$ & $2,5 \pm 0,17 \mathrm{efg}$ & $0,0 \pm 0,0 \mathrm{a}$ & $0,0 \pm 0,0 \mathrm{a}$ & $0,0 \pm 0,0 \mathrm{a}$ \\
Aries & $2,7 \pm 0,51 \mathrm{fgh}$ & $2,5 \pm 0,17 \mathrm{efg}$ & $1,3 \pm 0,99 \mathrm{bc}$ & $0,0 \pm 0,0 \mathrm{a}$ & $0,0 \pm 0,0 \mathrm{a}$ \\
Cigeulis & $1,5 \pm 0,17 \mathrm{c}$ & $1,5 \pm 0,38 \mathrm{~cd}$ & $0,0 \pm 0,0 \mathrm{a}$ & $0,0 \pm 0,0 \mathrm{a}$ & $0,0 \pm 0,0 \mathrm{a}$ \\
\hline \multicolumn{5}{l}{ Keterangan: Angka yang diikuti oleh huruf berbeda adalah berbeda nyata pada taraf } \\
\multicolumn{5}{c}{ signifikansi 5\%. }
\end{tabular}

pada perlakuan PEG $-0,25$ sedangkan pada perlakuan PEG -0,5, - $-0,75$ dan 1 tidak terlihat pula akar seminal yang tumbuh. Akar seminal padi varietas Superwin dapat tumbuh sampai perlakuan PEG - 1 dan tidak berbeda dengan perlakuan PEG 0 . Panjang akar padi varietas Serayu dan Cigeulis dengan perlakuan PEG 0 dan PEG $0,25 \mathrm{MPa}$ lebih besar dari perlakuan lainnya. Panjang akar pada varietas Aries dengan perlakuan PEG 0 dan 0,25 MPa lebih besar dari pada perlakuan lainnya. Akar seminal pada varietas Superwin masih tumbuh pada perlakuan PEG $-0,75 \mathrm{MPa}$ dengan mengabaikan anomali pada perlakuan PEG -1 MPa. Hasil ini menunjukkan bahwa varietas Superwin lebih toleran terhadap kekeringan dibandingkan dengan varietas lain.

Berkurangnya panjang akar seminal pada larutan PEG dengan PA yang semakin rendah disebabkan karena potensial air yang ada semakin berkurang sehingga menyebabkan kekeringan dan dapat mempengaruhi pertumbuhan akar kecambah tersebut. Air dapat masuk melalui penyerapan oleh akar. Proses penyerapan air ini berguna untuk melunakkan kulit biji dan menyebabkan pengembangan embrio dan endosperma dan akhirnya kulit biji akan pecah atau robek. Kebutuhan air yang tidak terpenuhi atau cekaman kekeringan mampu menurunkan panjang akar yang disebabkan karena kurangnya air yang masuk ke dalam tanaman. Air berperan penting dalam metabolisme tanaman (Sufianto 2004).

\section{Panjang Tunas}

Panjang tunas dari 7 varietas padi dengan 5 macam perlakuan PEG dapat dilihat pada Tabel 2. Hasil analisis sidik ragam menunjukkan bahwa faktor varietas, PEG, dan interaksi antara faktor varietas dan PEG menyebabkan perbedaan panjang tunas yang nyata sehingga dilanjutkan dengan uji BNT 5\%.

Panjang tunas kecambah padi Beras Merah dengan perlakuan PEG 0 lebih besar dari pada perlakuan PEG $-0,25,-0,5$, sedangkan pada perlakuan PEG $-0,75$ dan -1 tidak terlihat tunas yang tumbuh. Hal tersebut juga terjadi pada varietas padi IR 64 dan Burungan. Sedangkan pada varietas padi Superwin hanya pada perlakuan PEG $-0,75$ yang tidak terlihat panjang tunas yang tumbuh. 
Ballo dkk., Respons morfologis beberapa ....91

Pertumbuhan kecambah padi hampir sama pada varietas padi Serayu, dan Cigeulis, yaitu pada perlakuan PEG -

$0,5, \quad-0,75$ dan -1 tidak terdapat panjang tunas yang tumbuh. Pertumbuhan tunas masih dapat

Tabel 2. Panjang tunas $(\mathrm{cm}) 7$ varietas kecambah padi dengan 5 macam perlakuan PEG (Rata-rata \pm Standar Deviasi)

\begin{tabular}{llllrl}
\hline \multirow{2}{*}{ Varietas } & \multicolumn{5}{c}{ PEG (MPa) } \\
\cline { 2 - 6 } & \multicolumn{1}{c}{0} & \multicolumn{1}{c}{$-0,25$} & $-0,5$ & $-0,75$ & -1 \\
\hline Beras Merah & $2,8 \pm 0,33 \mathrm{f}$ & $0,5 \pm 0,1 \mathrm{bc}$ & $0,5 \pm 0,1 \mathrm{bc}$ & $0,0 \pm 0,0 \mathrm{a}$ & $0,0 \pm 0,0 \mathrm{a}$ \\
IR 64 & $2,0 \pm 0,22 \mathrm{e}$ & $0,4 \pm 0,17 \mathrm{bc}$ & $0,0 \pm 0,0 \mathrm{a}$ & $0,0 \pm 0,0 \mathrm{a}$ & $0,0 \pm 0,0 \mathrm{a}$ \\
Burungan & $2,0 \pm 0,12 \mathrm{de}$ & $0,8 \pm 0,07 \mathrm{c}$ & $0,3 \pm 0,1 \mathrm{~b}$ & $0,0 \pm 0,0 \mathrm{a}$ & $0,0 \pm 0,0 \mathrm{a}$ \\
Superwin & $0,6 \pm 0,17 \mathrm{bc}$ & $0,6 \pm 0,1 \mathrm{bc}$ & $0,6 \pm 0,1 \mathrm{bc}$ & $0,0 \pm 0,0 \mathrm{a}$ & $0,5 \pm 0,15 \mathrm{bc}$ \\
Serayu & $0,6 \pm 0,22 \mathrm{bc}$ & $0,7 \pm 0,1 \mathrm{bc}$ & $0,0 \pm 0,0 \mathrm{a}$ & $0,0 \pm 0,0 \mathrm{a}$ & $0,0 \pm 0,0 \mathrm{a}$ \\
Aries & $0,7 \pm 0,07 \mathrm{c}$ & $0,6 \pm 0,17 \mathrm{bc}$ & $0,6 \pm 0,3 \mathrm{bc}$ & $0,0 \pm 0,0 \mathrm{a}$ & $0,0 \pm 0,0 \mathrm{a}$ \\
Cigeulis & $0,5 \pm 0,35 \mathrm{bc}$ & $0,4 \pm 0,24 \mathrm{bc}$ & $0,0 \pm 0,0 \mathrm{a}$ & $0,0 \pm 0,0 \mathrm{a}$ & $0,0 \pm 0,0 \mathrm{a}$ \\
\hline
\end{tabular}

Keterangan: Angka yang diikuti oleh huruf berbeda adalah berbeda nyata pada taraf signifikansi $5 \%$.

diamati pada benih varietas Beras Merah, Burungan, Superwin, dan Aries yang dikecambahkan pada larutan -0,5 MPa.

Perlakuan PEG dengan PA yang semakin rendah dapat menghambat pertambahan panjang tunas karena PEG bersifat mengikat air sehingga mampu menurunkan potensial air medium (Graham 1992). Ukuran polimer PEG yang semakin besar dapat menghambat air yang masuk ke dalam sel. Cekaman kekeringan dapat menghambat perkecambahan benih, menurunkan produksi dan efisiensi penggunaan air (Harsono et al. 2003). Hal tersebut menyebabkan panjang tunas menurun pada perlakuan PEG dengan PA yang makin rendah. Cekaman kekeringan tersebut menyebabkan tanaman mengalami kekurangan air. Air memiliki peran penting dalam pertumbuhan kecambah yaitu sebagai medium untuk reaksi kimia, bahan baku fotosintesis, proses hidrolisis dan reaksi kimia lainnya (Gardner 1991)

\section{Persentase Perkecambahan} Angka persentase perkecambahan diperoleh dari jumlah benih yang berkecambah dibagi total benih yang dikecambahkan, Ialu dikalikan $100 \%$. Persentase perkecambahan dari 7 varietas padi dengan 5 macam perlakuan PEG dapat dilihat pada Tabel 3. Hasil analisis sidik ragam menunjukkan bahwa faktor varietas, PEG, dan interaksi antara varietas dan PEG menyebabkan perbedaan persentase perkecambahan yang nyata sehingga dilanjutkan dengan uji BNT 5\%.

Persentase perkecambahan pada PEG $0 \mathrm{MPa}$ lebih besar dibandingkan dengan -0,25 dan -0,5 $\mathrm{MPa}$. Bahkan pada perlakuan PEG 0,75 dan -1 MPa tidak terlihat ada kecambah yang tumbuh, kecuali terdapat pada varietas padi Superwin yang terdapat kecambah yang tumbuh pada semua perlakuan PEG. Kemampuan benih padi Superwin yang masih berkecambah pada perlakuan PEG $-0,75 \quad \mathrm{MPa}$ menunjukkan bahwa Superwin lebih toleran terhadap kekeringan dibandingkan dengan varietas padi lainnya. Perbedaan tersebut diakibatkan karena potensial air medium yang semakin rendah mengakibatkan sel tumbuhan tidak 
dapat mengambil air dari medium. Cekaman kekeringan merupakan akibat keterbatasan air dari lingkungan yaitu media tanam (Kusmarwiyah et al. 2006).

Proses perkecambahan terjadi karena adanya aktivitas metabolisme dari biji. Biji yang akan berkecambah membutuhkan air untuk merangsang hormon pertumbuhan dan menambah kandungan air pada setiap bagian yang mulai tumbuh pada saat perkecambahan. Oleh karena itu, jika kekurangan air maka proses metabolisme pada benih yang semula aktif menjadi terhenti sehingga proses perkecambahan akan terganggu. Hanya benih yang toleran kekeringan saja yang mampu berkecambah. Tanaman mempunyai toleransi yang berbeda terhadap kekeringan karena perbedaan dalam mekanisme morfologi, fisiologi, biokimia dan molekuler (Lestari dan Mariska 2006). istilah untuk menyatakan bahwa tanaman mengalami kekurangan air

\section{Rasio Panjang Akar Seminal : Panjang Tunas}

Rasio panjang akar seminal : panjang tunas dari 7 varietas padi dengan 5 macam perlakuan PEG dapat dilihat pada Tabel 4. Hasil analisis sidik ragam menunjukkan bahwa faktor varietas, PEG, dan interaksi menyebabkan perbedaan rasio panjang akar seminal : panjang tunas yang nyata sehingga dilanjutkan dengan uji BNT 5\%. Rasio panjang akar seminal : panjang tunas dapat diukur sampai pada perlakuan PEG $0,5 \mathrm{MPa}$ hanya pada varietas Beras Merah, Superwin, dan Aries dengan mengabaikan anomali pada PEG -1 $\mathrm{MPa}$.

Tabel 3. Persentase perkecambahan (\%) 7 varietas kecambah padi dengan 5 macam perlakuan PEG (Rata-rata \pm Standar Deviasi)

\begin{tabular}{|c|c|c|c|c|c|}
\hline \multirow{2}{*}{ Varietas } & \multicolumn{5}{|c|}{ PEG (MPa) } \\
\hline & 0 & $-0,25$ & $-0,5$ & $-0,75$ & -1 \\
\hline Beras Merah & $65,33 \pm 6,10 \mathrm{k}$ & $45,33 \pm 12,84 \mathrm{hi}$ & $20 \pm 8$ de & $0,0 \pm 0,0 \mathrm{a}$ & $0,0 \pm 0,0 \mathrm{a}$ \\
\hline IR 64 & $48 \pm 4 \mathrm{ij}$ & $26,66 \pm 6,10$ efg & $0,0 \pm 0,0 \mathrm{a}$ & $0,0 \pm 0,0$ a & $0,0 \pm 0,0 \mathrm{a}$ \\
\hline Burungan & $29,33 \pm 8,32 \mathrm{fg}$ & $18,66 \pm 4,61 \mathrm{de}$ & $0,0 \pm 0,0 \mathrm{a}$ & $0,0 \pm 0,0 \mathrm{a}$ & $0,0 \pm 0,0 \mathrm{a}$ \\
\hline Superwin & $58,66 \pm 10,06$ jk & $36 \pm 12 \mathrm{gh}$ & $16 \pm 4 d$ & $\pm 2,30 \mathrm{~b}$ & $20 \pm 8$ de \\
\hline Ser & $44 \pm$ & 92 ef & $0,0 \pm 0,0 \mathrm{a}$ & $0,0 \mathrm{a}$ & $0,0 \pm 0,0 \mathrm{a}$ \\
\hline Aries & $46,66 \pm 14,02$ hi & $32 \pm 12 \mathrm{fg}$ & $2,66 \pm 2,30 \mathrm{~b}$ & $0,0 \pm 0,0 \mathrm{a}$ & $0,0 \pm 0,0 \mathrm{a}$ \\
\hline Cigeulis & $16 \pm 4 d$ & $9,33 \pm 2,30 \mathrm{c}$ & $0,0 \pm 0,0 \mathrm{a}$ & $0,0 \pm 0,0 \mathrm{a}$ & $0,0 \pm 0,0 \mathrm{a}$ \\
\hline
\end{tabular}

Keterangan: Angka yang diikuti oleh huruf berbeda adalah berbeda nyata pada taraf signifikansi $5 \%$.

Tabel 4. Rasio panjang akar seminal : panjang tunas 7 varietas kecambah padi dengan 5 macam perlakuan PEG (Rata-rata \pm Standar Deviasi)

\begin{tabular}{llcccc}
\hline \multirow{2}{*}{ Varietas } & \multicolumn{5}{c}{ PEG (MPa) } \\
\cline { 2 - 6 } & 0 & $-0,25$ & $-0,5$ & $-0,75$ & -1 \\
\hline Beras Merah & $1,3 \pm 0,35 \mathrm{bc}$ & $2,6 \pm 0,95 \mathrm{ij}$ & $2,2 \pm 1,07 \mathrm{hij}$ & $0,0 \pm 0,0 \mathrm{~b}$ & $0,0 \pm 0,0 \mathrm{~b}$ \\
IR 64 & $2,1 \pm 0,23 \mathrm{cdef}$ & $2,5 \pm 0,45 \mathrm{j}$ & $0,0 \pm 0,0 \mathrm{~b}$ & $0,0 \pm 0,0 \mathrm{~b}$ & $0,0 \pm 0,0 \mathrm{~b}$ \\
Burungan & $1,5 \pm 0,41 \mathrm{bcde}$ & $1,9 \pm 0,66 \mathrm{fgh}$ & $0,0 \pm 0,0 \mathrm{a}$ & $0,0 \pm 0,0 \mathrm{~b}$ & $0,0 \pm 0,0 \mathrm{~b}$ \\
Superwin & $1,8 \pm 0,26 \mathrm{fghi}$ & $1,7 \pm 0,15 \mathrm{fghi}$ & $1,4 \pm 0,23 \mathrm{efgh}$ & $0,0 \pm 0,0 \mathrm{~b}$ & $1,7 \pm 0,61 \mathrm{ghij}$ \\
Serayu & $1,9 \pm 0,25 \mathrm{ghij}$ & $1,8 \pm 0,2 \mathrm{fghi}$ & $0,0 \pm 0,0 \mathrm{~b}$ & $0,0 \pm 0,0 \mathrm{~b}$ & $0,0 \pm 0,0 \mathrm{~b}$ \\
Aries & $2,0 \pm 0.14 \mathrm{fghi}$ & $1,9 \pm 0,26 \mathrm{ghi}$ & $0,7 \pm 0,96 \mathrm{bcd}$ & $0,0 \pm 0,0 \mathrm{~b}$ & $0,0 \pm 0,0 \mathrm{~b}$ \\
Cigeulis & $1,0 \pm 0,21$ defg & $1,1 \pm 0,3$ efgh & $0,0 \pm 0,0 \mathrm{~b}$ & $0,0 \pm 0,0 \mathrm{~b}$ & $0,0 \pm 0,0 \mathrm{~b}$ \\
\hline \multicolumn{5}{l}{ Keterangan: Angka yang diikuti oleh huruf berbeda adalah berbeda nyata pada taraf signifikansi $5 \%}$.
\end{tabular}


Perhitungan indeks rasio panjang akar seminal : panjang tunas (Widoretno et al. 2002) adalah 169 untuk Beras Merah, 78 untuk Superwin, dan 35 untuk Aries. Hasil penelitian ini menunjukkan bahwa Beras Merah juga potensial sebagai varietas padi yang toleran terhadap kekeringan di samping Superwin.

Rasio panjang akar seminal : panjang tunas dapat mengindikasikan ketahanan padi yang bervigor tinggi terhadap cekaman kekeringan (Junaidi 1998). Pada kondisi kekeringan rasio panjang akar seminal : panjang tunas meningkat karena pertumbuhan daun lebih banyak berkurang dibandingkan dengan pertumbuhan akar (Condon 1982 dalam Nio 2009), translokasi hasil fotosintesis yang lebih banyak ke sistem perakaran (Azhiri-Sigari et al. 2000) dan adanya sinyal hormonal yang diiduksi di akar sebagai respons terhadap kekurangan air (Sharp dan Davis 1989).

\section{Indeks Vigor Benih}

Nilai indeks vigor benih diperoleh dari panjang akar seminal ditambah panjang tunas lalu dikalikan persentase perkecambahan. Indeks Vigor Benih dari 7 varietas padi dengan 5 macam perlakuan PEG dapat dilihat pada Tabel 5. Hasil analisis sidik ragam menunjukkan bahwa faktor varietas, PEG, dan interaksi antara varietas dan PEG menyebabkan perbedaan indeks vigor benih yang nyata sehingga dilanjutkan dengan uji BNT 5\%.

Berdasarkan hasil pada Tabel 5 menunjukkan bahwa indeks vigor benih makin kecil jika larutan PEG yang dipakai sebagai media perkecambahan mempunyai potensial air semakin rendah. Indeks vigor benih pada varietas Beras Merah, Superwin, Aries masih dapat diamati saat perkecambahan pada larutan PEG dengan PA $-0,5$ MPa. Selanjutnya indeks vigor benih Superwin masih dapat diamati pada perkecambahan dengan larutan PEG $0,75 \mathrm{MPa}$ (data untuk PEG - $1 \mathrm{MPa}$ merupakan anomali). Seperti halnya pada panjang akar seminal dan persentase perkecambahan, perhitungan indeks vigor benih menunjukkan bahwa varietas Superwin lebih toleran dibandingkan dengan varietas lain. Hasil penelitian Nio et al. (2010) menunjukkan tidak adanya perbedaan indeks vigor benih pada kecambah padi varietas Mira 1 dan IR 64 dengan perlakuan PEG dengan PA 0 dan $-0,5 \mathrm{MPa}$. Perkecambahan benih gandum dengan larutan osmotikum PEG 6000 dengan PA -10 bar sebagai simulasi

Tabel 5. Indeks vigor benih 7 varietas kecambah padi dengan 5 macam perlakuan PEG (Rata-rata \pm SD)

\begin{tabular}{llllll}
\hline \multirow{2}{*}{ Varietas } & \multicolumn{5}{c}{ PEG (MPa) } \\
\cline { 2 - 6 } & \multicolumn{1}{c}{0} & \multicolumn{1}{c}{$-0,25$} & \multicolumn{1}{c}{$-0,5$} & \multicolumn{1}{c}{$-0,75$} & \multicolumn{1}{c}{-1} \\
\hline Beras Merah & $4,6 \pm 0,34 \mathrm{n}$ & $1,6 \pm 0,1 \mathrm{kl}$ & $0,7 \pm 0,46 \mathrm{efg}$ & $0,0 \pm 0,0 \mathrm{a}$ & $0,0 \pm 0,0 \mathrm{a}$ \\
IR 64 & $3,0 \pm 0,22 \mathrm{~m}$ & $0,91 \pm 0,22 \mathrm{ghi}$ & $0,0 \pm 0,0 \mathrm{a}$ & $0,0 \pm 0,0 \mathrm{a}$ & $0,0 \pm 0,0 \mathrm{a}$ \\
Burungan & $1,61 \pm 0,37 \mathrm{kl}$ & $0,66 \pm 0,22 \mathrm{efg}$ & $0,0 \pm 0,0 \mathrm{a}$ & $0,0 \pm 0,0 \mathrm{a}$ & $0,0 \pm 0,0 \mathrm{a}$ \\
Superwin & $1,83 \pm 0,28 \mathrm{I}$ & $1,07 \pm 0,31 \mathrm{ij}$ & $0,41 \pm 0,1 \mathrm{de}$ & $0,03 \pm 0,09 \mathrm{ab}$ & $0,57 \pm 0,28 \mathrm{def}$ \\
Serayu & $1,4 \pm 0,17 \mathrm{jk}$ & $0,76 \pm 0,2 \mathrm{fgh}$ & $0,0 \pm 0,0 \mathrm{a}$ & $0,0 \pm 0,0 \mathrm{a}$ & $0,0 \pm 0,0 \mathrm{a}$ \\
Aries & $1,66 \pm 0,74 \mathrm{kl}$ & $1,04 \pm 0,42 \mathrm{hij}$ & $0,07 \pm 0,08 \mathrm{~b}$ & $0,0 \pm 0,0 \mathrm{a}$ & $0,0 \pm 0,0 \mathrm{a}$ \\
Cigeulis & $0,34 \pm 0,14 \mathrm{~cd}$ & $1,19 \pm 0,1 \mathrm{c}$ & $0,0 \pm 0,0 \mathrm{a}$ & $0,0 \pm 0,0 \mathrm{a}$ & $0,0 \pm 0,0 \mathrm{a}$ \\
\hline
\end{tabular}

Keterangan: Angka yang diikuti oleh huruf berbeda adalah berbeda nyata pada taraf signifikansi $5 \%$. 


\section{JURNAL BIOSLOGOS, AGUSTUS 2012, VOL. 2 NOMOR 2}

cekaman kekeringan menurunkan indeks vigor benih sampai $85,8 \%$ (Dhanda et al. 2004).

Secara umum ketujuh varietas padi yang diiuji masih menunjukkan respons morfologis terhadap cakaman kekeringan yang diinduksi dengan PEG sampai dengan PA -0,5 MPa. Varietas Superwin menunjukkan kemampuan toleransi terhadap kekeringan yang lebih tinggi dari pada varietas lain, karena kecambah padi masih menunjukkan pertumbuhan pada larutan PEG dengan PA yang lebih rendah dari pada $-0,5 \mathrm{MPa}$ (Tabel 1, 3 dan 5). Adanya pertumbuhan dapat diamati berdasarkan parameter panjang akar seminal, persentase perkecambahan dan indeks vigor benih. Tetapi terdapat anomali pada ciri-ciri morfologi varietas Superwin yang diamati pada perlakuan PEG -1 MPa, yaitu terjadinya peningkatan pertumbuhan dengan bertambahnya intensitas kekeringan. Hal ini terjadi karena tidak semua benih yang digunakan untuk perlakuan tersebut berkecambah dan tumbuh dengan baik, sehingga tidak tersedia 10 kecambah yang representatif untuk memperoleh data ciri-ciri morfologi untuk tiap replikasi. Kondisi percobaan ini terlihat pada besarnya nilai standar deviasi yang menunjukkan ketidaksenggaman data yang diperoleh. Salah satu penyebab anomali ini adalah posisi benih dalam container yang tidak mendukung perkecambahan dan pertumbuhan yang optimal.

\section{KESIMPULAN}

Terdapat perbedaan respons morfologis terhadap kekeringan yang diinduksi dengan PEG 8000 pada fase perkecambahan di antara ketujuh varietas padi. Panjang akar seminal, panjan tunas, rasio panjang akar seminal : panjang tunas, persentase perkecambahan dan indeks vigor benih dapat dipakai sebagai indikator toleransi kekeringan yang potensial pada fase perkecambahan padi. Toleransi varietas Superwin terhadap kekeringan yang diinduksi dengan PEG 8000 pada fase perkecambahan lebih tinggi daripada varietas padi lainnya.

\section{DAFTAR PUSTAKA}

Azhiri-Sigari T, Yamauchi A, Kamoshita A, Wade LJ (2000) Genotypic variation in response of rainfed lowland rice to drought and rewatering, II Root growt. Plant. Prod. Sci. 3:180-188

Dhanda SS, Sethi GS, Behl RK (2004) Indices of drought tolerance in wheat genotypes at early stages of plant growth. Departement of Plant Breeding, CCS Haryana Agricultural University, Hisar, India

Emmerich WE, Hardegree SP (1991) Seed germination in polyethylene glycol solution: effect of filter paper exclusion. Crop Sci. 31:454-458

Gardner FP, Pearce RB, Mitchell R L (1991) Fisiologi tanaman budidaya. Universitas Indonesia. Jakarta

Gardner FP, Pearce RB, Mitchell R L (1991) Fisiologi tanaman budidaya. Universitas Indonesia. Jakarta

Gregory PJ (1989) The role of root characteristics in moderating the effect of drought. Dalam: Baker FWG (ed) Drought resistance in cereals, CAB International, Wallingford, UK, pp141-150

Harsono A, Tohari, Indradewa D, Adisarwanto T (2003) Ketahanan dan aktivitas fisiologi beberapa genotipe kacang tanah pada cekaman kekeringan. Jurnal Penelitian Balai Tanaman Kacang dan Umbi-umbian (BALITKABI). IImu Pertanian 10: 51-62 
Kumar A, Singh DP (1998) Use of physiological indice as a screening technique for drought tolerance in oilseed brassica species. Ann. Bot. 81:413-420.

Kusmarwiyah, Indradewa D, Suyadi (2006) Kajian fisiologis cekaman kekeringan pada jagung manis. Jurnal Agrosains 19 :225-235

Lestari EG, Mariska I (2006) Identifikasi somaklon padi Gajahmungkur, Towuti dan IR 64 tahan kekeringan menggunakan polyehylene glycol. Bul. Agron. 34:71-78

Nio SA (2009) Osmotic adjustment and solutes in wheat (Triticum aestivum L.) during water deficit. Disertasi. University of Western Australia, Perth

Nio SA, Ballo M (2010) Peranan air dalam perkecambahan biji. Jurnal Ilmiah Sains 10: 190-195

Premchandra GS, Sameoka H, Ogata S (1990) Cell osmotic membranestability, an indication of drought tolerance, as affiected by applied nitrogen in soil. J Agric Res 115: 63-66

Sharp RE, Davis WJ (1989) Regulations of growth and development of plants growing with a restricted supply of water. Dalam: Jones HG, Flowers TJ, Jones MB (eds) Plant under stress, Cambridge University Press, Cambrigde, pp 71-93
Sufianto, 2004. Kajian cekaman air dan jumlah ginophore kacang tanah (Arachis hypogaea L.) Tropika Jurnal Penelitian Pertanian 12

Winter SR, Musick TJ, Porter KB (1988) Evaluation of screening techniques for breeding drought resistance winter wheat. Crop Sci 28:512-516 